\title{
A 576-YEAR WEBER RIVER STREAMFLOW RECONSTRUCTION FROM TREE RINGS FOR WATER RESOURCE RISK ASSESSMENT IN THE WASATCH FRONT, UTAH ${ }^{1}$
}

\author{
Matthew F. Bekker, R. Justin DeRose, Brendan M. Buckley, Roger K. Kjelgren, and Nathan S. Gill ${ }^{2}$
}

\begin{abstract}
We present a 576-year tree-ring-based reconstruction of streamflow for northern Utah's Weber River that exhibits considerable interannual and decadal-scale variability. While the 20th Century instrumental period includes several extreme individual dry years, it was the century with the fewest such years of the entire reconstruction. Extended droughts were more severe in duration, magnitude, and intensity prior to the instrumental record, including the most protracted drought of the record, which spanned 16 years from 1703 to 1718 . Extreme wet years and periods are also a regular feature of the reconstruction. A strong early 17th Century pluvial exceeds the early 20th Century pluvial in magnitude, duration, and intensity, and dwarfs the 1980s wet period that caused significant flooding along the Wasatch Front. The long-term hydroclimatology of northern Utah is marked by considerable uncertainty; hence, our reconstruction provides water managers with a more complete record of water resource variability for assessment of the risk of droughts and floods for one of the largest and most rapidly growing population centers in the Intermountain West.
\end{abstract}

(KEY TERMS: dendrochronology; drought; paleohydrology; planning; Utah.)

Bekker, Matthew F., R. Justin DeRose, Brendan M. Buckley, Roger K. Kjelgren, and Nathan S. Gill, 2014. A 576-Year Weber River Streamflow Reconstruction from Tree Rings for Water Resource Risk Assessment in the Wasatch Front, Utah. Journal of the American Water Resources Association (JAWRA) 50(5): 1338-1348. DOI: $10.1111 /$ jawr.12191

\section{INTRODUCTION}

Utah is the second driest and third fastest growing state in the United States (U.S.), experiencing a $23.8 \%$ increase in population from 2000 to 2010 (Mackun and Wilson, 2011). Eighty percent of this population is concentrated along the Wasatch Front, a chain of metropolitan areas located west of the Wasatch Mountain Range from central Utah to the Idaho border. This region is heavily dependent on snowmelt runoff delivered via rivers with headwaters in the Wasatch and Uinta Mountains to the east. Despite extensive water development projects, recent severe droughts have strained water supplies. For example, statewide reservoir levels dropped below 50\% in 2002 (DNR, 2007).

The Weber River Basin encompasses four northern Utah counties and receives an average of $660 \mathrm{~mm}$ of precipitation annually, more than any other major river basin in the state (UDWR, 2009) (Figure 1).

\footnotetext{
${ }^{1}$ Paper No. JAWRA-13-0190-P of the Journal of the American Water Resources Association (JAWRA). Received September 4, 2013; accepted February 18, 2014. (C) 2014 American Water Resources Association. Discussions are open until six months from print publication.

${ }^{2}$ Associate Professor (Bekker), Department of Geography, Brigham Young University, 690 SWKT, Provo, Utah 84602; Research Ecologist (DeRose), Forest Inventory and Analysis, Rocky Mountain Research Station, U.S. Forest Service, Ogden, Utah 84401; Lamont Research Professor (Buckley), Tree-Ring Laboratory, Lamont-Doherty Earth Observatory of Columbia University, Palisades, New York 10964; Associate Professor (Kjelgren), Department of Plants, Soils and Climate, Utah State University, Logan, Utah 84322; and Undergraduate Student (Gill), Department of Geography, Brigham Young University, Provo, Utah 84602 (E-Mail/Bekker: matthew_bekker@byu.edu).
} 


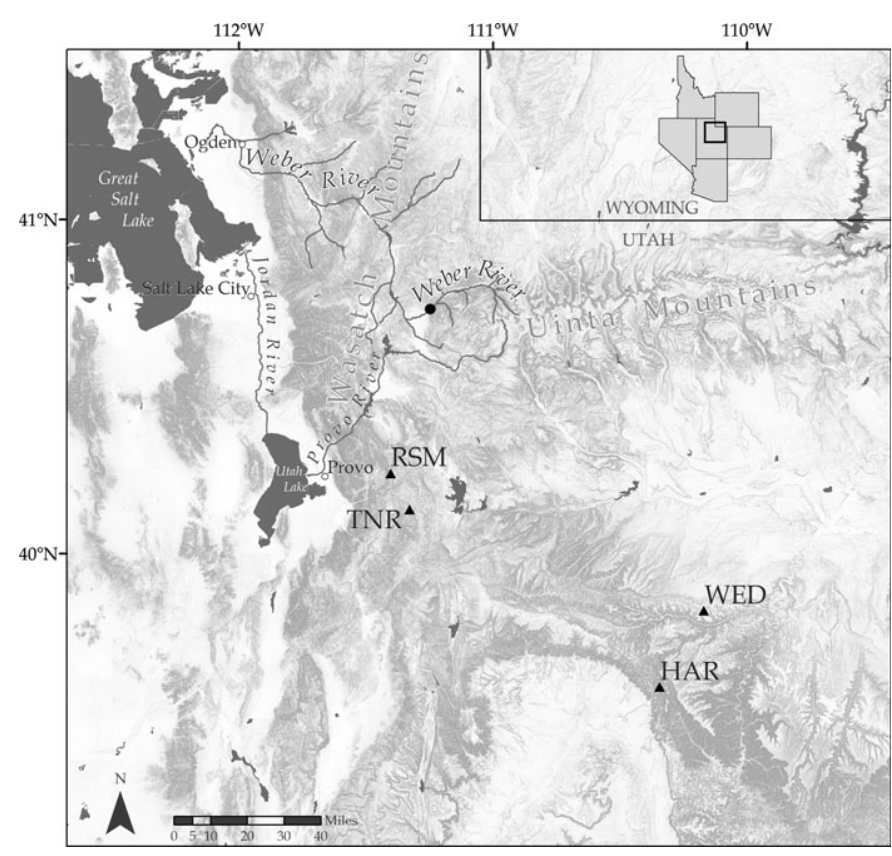

FIGURE 1. Map Showing the Weber River Basin with Headwaters in the Western Uinta Mountains, and Other Tributaries Joining via the Wasatch Range. The tree-ring chronologies (triangles) used to reconstruct streamflow for the Weber River gauge near Oakley, Utah (filled circle) are also shown, along with major metropolitan areas along the Wasatch Front that are dependent on water delivered by rivers such as the Weber.

The Weber River is also one of the most important sources of water for the Wasatch Front. The river is highly developed and has been used historically for agriculture, but is being rapidly converted to municipal \& industrial (M\&I) use. In 2005 M\&I use was 254 million cubic meters $(\mathrm{mcm})$, and is expected to increase to $323 \mathrm{mcm}$ by 2030 and $396 \mathrm{mcm}$ by 2060 , even if new water conservation plans are implemented (UDWR, 2009).

Planning for increased water use and drought mitigation can be enhanced via a long-term view of the frequency, magnitude, and intensity of fluctuations in streamflow for the key rivers that deliver water to municipal and agricultural areas. However, instrumental records for most rivers rarely cover more than 100 years, and the Weber is no exception. Because streamflow and annual growth rings in trees are both directly influenced by precipitation, temperature, and soil moisture, tree rings can be used to extend records of hydroclimate several centuries into the past. Robust reconstructions of streamflow have been produced for several basins in the Intermountain West (e.g., Meko and Stockton, 1984; Woodhouse, 2001; Carson and Munroe, 2005; Woodhouse and Lukas, 2006a; Watson et al., 2009; Barnett et al., 2010; Wise, 2010a; Gray et al., 2011; Meko et al., 2012). Most of these reconstructions suggest that the instrumental record is an insufficient base for water management, as droughts in previous centuries have often exceeded those of the past 100 years in duration and magnitude. Another common theme is that while some droughts have been coherent in space and time across the entire western U.S. (Woodhouse et al., 2009; Wise, 2012), others have been discontinuous and important differences have been observed across basins and even subbasins (Woodhouse and Lukas, 2006b; Watson et al., 2009; Gray et al., 2011).

Despite these efforts, streamflow reconstructions and tree-ring data are still sparse in parts of the Intermountain West (Wise, 2012), and one such gap occurs in the eastern Great Basin where the Wasatch Front is located. The hydroclimatology of this region is complex due in part to the juxtaposition of the north-south trending Wasatch Mountains, which ostensibly provide a barrier to Pacific storm tracks (Pope and Brough, 1996), and the higher elevation $(4,120 \mathrm{~m})$ but east-west trending Uinta Mountains to the east (Figure 1), both of which serve as the headwaters for streams flowing to the Wasatch Front. Analyses of precipitation regimes in the Intermountain West have identified a precipitation dipole, a generalized pattern associated with Pacific teleconnections whereby the Pacific Northwest is wet when the Southwest is dry and vice versa (Mock, 1996; Cayan et al., 1999; Brown and Comrie, 2004; Wang et al., 2010; Wise, 2012). The location of the fulcrum of the dipole has been unstable over space and time (Wise, 2010b; DeRose et al., 2013), complicating our understanding of regional hydroclimatology. Modeling studies by Seager et al. (2007) predict that the southwestern U.S., including northern Utah, will experience drier conditions under climate change scenarios.

These characteristics produce considerable uncertainty regarding water resource management along the Wasatch Front, highlighting the need for better understanding of hydroclimatic variability at a finer spatial scale and broader temporal scale than is currently available for risk assessment. Our objectives were to (1) establish a more extensive network of moisture-sensitive tree-ring chronologies in one of the most heavily populated areas in the Intermountain West; (2) reconstruct streamflow beyond the instrumental record for an essential Wasatch Front river, using our new chronologies and previously published chronologies from the region; and (3) provide water managers with a basis for risk assessment of extreme dry and wet events.

\section{DATA AND METHODS}

\section{Streamflow Data}

We obtained instrumented streamflow records from U.S. Geological Survey Gauge \#10128500 (USGS, 2013) 
Bekker, DeRose, Buckley, Kuelgren, and Gill

for the upper Weber River near Oakley, Utah, an area that receives $914 \mathrm{~mm}$ of precipitation per year (UDWR, 2009). Daily discharge records for the gauge have been kept continuously since October 1904. The gauge is ideally located below all of the major headwater streams in the northwestern Uinta Mountains (Figure 1), but above all diversions except for Smith \& Morehouse Reservoir. This small, "fill and spill" reservoir interrupts only one of the headwater streams, and was constructed in 1925 with a capacity of $1.7 \mathrm{mcm}$, and expanded to $9.6 \mathrm{mcm}$ ( $5 \%$ of mean annual flow of the Weber near Oakley) in 1987. We adjusted for flow alterations since the 1987 expansion and found no difference in correlation between wateryear (October-September) discharge and tree-ring width.

\section{Tree-Ring Chronologies}

Because regional climate patterns in northern Utah are variable over space and time (Woodhouse and Kay, 1990; Brown and Comrie, 2004; Tingstad and MacDonald, 2010; Wise, 2010b), we delineated a large region that encompasses northern Utah, northeastern Nevada, southeastern Idaho, southwestern Wyoming, and northwestern Colorado from which to investigate the relationship between streamflow and tree-ring chronologies from the International TreeRing Data Bank (ITRDB) and from new collections. We then restricted the size of this region based on the correlation between the chronologies and streamflow. Individual chronologies that were to be used as predictors were screened further based on a common period of record spanning at least 1450-2005 A.D.

To improve the spatial and temporal coverage of tree-ring data, we also developed several new treering site collections in the region. For these sites, we selected open stands of known moisture-sensitive species (Hidalgo et al., 2001), including pinyon pine (Pinus edulis and P. monophylla), Douglas-fir (Pseudotsuga menziesii), ponderosa pine ( $P$. ponderosa), and limber pine ( $P$. flexilis). We further selected trees growing on south-facing, steep, rocky slopes, or ridge tops with little soil development to increase the likelihood that moisture was the factor most limiting to growth. As per standard protocols for dendroclimatology (sensu Fritts, 1976) we extracted at least two cores per tree where possible.

Samples were prepared with progressively finer sandpaper to 600 grit and $9 \mu \mathrm{m}$ finishing film, until individual cells were clearly visible under a binocular microscope. The tree-ring series were then cross-dated using skeleton plots and the memorization method (Speer, 2010), to assign a precise calendar year to each ring. The rings were then measured to within
$0.001 \mathrm{~mm}$, and dating accuracy was checked using the computer program COFECHA (Holmes, 1983). This program compares the ring widths in a given series to a master chronology made up of all other series and produces a suite of statistics to evaluate dating accuracy. To remove nonclimatic (e.g., geometric) growth trends and produce a dimensionless ring-width index from the tree-ring series, we used Friedman's (1984) variable span smoother with the alpha level set to 7, in the computer program ARSTAN (Cook et al., 2007). This approximates a moderately flexible smoothing spline and thus retains some low frequency variation. We inspected the detrended series individually to ensure that most variation that was common among all series was retained, and less common variation likely not due to climate was removed.

\section{Modeling Streamflow}

We used multiple linear regression to model and reconstruct streamflow from the tree-ring series. However, because multiple predictors can artificially inflate explained variance (Fritts, 1991), we used principal components analysis to extract the major modes of variability from the chronologies by using current-year, previous-year, and following-year growth as predictors of water-year streamflow. We screened for components with eigenvalues that exceeded 1, and used maximum $r^{2}$ to select the regression model (Fritts et al., 1990). We assessed the strength of the model using $r^{2}$ and adjusted $r^{2}$, and performed rigorous split calibration/verification tests to assess reconstruction fidelity using reduction of error and coefficient of efficiency tests (see Fritts, 1976). We also used the Durbin-Watson statistic (Draper and Smith, 1998) to determine whether autocorrelation was present in the residuals. The expressed population signal (EPS) is a measure of the common variance in a chronology and provides guidance for evaluating the reliability of a reconstruction with decreasing sample depth further back in time (Briffa, 1995). We examined 50-year segments overlapped by 25 years for each chronology, and noted where the EPS drops below 85\% as suggested by Wigley et al. (1984).

\section{Analysis of Extreme Events}

To investigate multiyear dry and wet periods that would be of particular interest in water management, we followed the runs analysis procedure of Gray et al. (2011). We determined departures from the instrumental mean streamflow for each year in the recon- 
struction and calculated the duration, magnitude (cumulative departure), and intensity (magnitude divided by duration) of consecutive years above or below the mean. We summed the magnitude and intensity of dry and wet periods separately to determine a "score" for each run.

We also investigated clusters of multiyear dry (wet) periods that were separated by only single years above (below) mean annual flow. In a management scenario, one above-average year may provide insufficient water to fill reservoirs following a multiyear drought, and if this pattern were repeated several times, the entire time period would be considered a drought (e.g., Meko et al., 2007; Woodhouse et al., 2010). Conversely, multiyear pluvial events with only single years below the mean would make flood management difficult. We analyzed clusters of any length that included at least two consecutive years below (above) the instrumental mean separated by only single years above (below) the mean, and calculated magnitude and intensity scores as above.

\section{RESULTS}

\section{Streamflow Reconstruction Model}

Following our screening procedures outlined above, we selected four tree-ring chronologies for modeling Weber River streamflow - two newly collected pinyon pine chronologies from just east of the crest of the Wasatch Mountains (Tanner Ridge, TNR and Rattlesnake Mountain, RSM), and two from the rain shadow of the Wasatch Range and south of the Uinta Mountains, Well's Draw Update (WED) (pinyon pine) (Pederson et al., 2011) and Harmon Canyon (Douglasfir) (Knight et al., 2010), respectively. These latter two datasets were obtained from the ITRDB (http:// www.ncdc.noaa.gov/paleo/treering.html; see Table 1 and Figure 1 for site details and locations).

These four chronologies effectively modeled the Weber River gauge record and yielded a reconstruction that extends from 1429 to 2004, and that explains $55 \%$ of the variance in the original time series. The reconstructed values effectively capture both interannual and lower frequency variation in the instrumental record (Figure 2). In particular, the most extreme dry years (e.g., 1934, 1977, and 2002) are predicted accurately, but the model underestimates most extremely high values (e.g., 1907, 1921, and 1986). Verification statistics indicate a robust reconstruction although the model performed better when calibrated on the latter half of the data compared to the early portion (Table 2). Durbin-Watson values indicate no significant autocorrelation problems. The EPS drops below $85 \%$ for RSM in 1480 and TNR in 1470, so the reconstruction and subsequent analyses are less reliable before that time.

\section{Extreme Droughts}

The reconstruction also exhibits strong interannual, decadal, and multidecadal-scale variability over the past five centuries (Figure 3). Extreme (5th percentile) individual dry years (i.e., drought years) are evident in the reconstruction (Table 3) and although some of these occur during the instrumental record (1934, 1977, and 2002), a ranking of extreme years (Table 4) shows that there are fewer in the 1900s than any previous century. The majority of dry years occur in the 1400s and 1500s. The runs analysis of dry periods indicates several droughts of at least two consecutive years (Figure 4). Three of the twenty-five most severe droughts based on overall score (Table 5) occur during the 100-year instrumental record, including 1930-1936 (tied for 8th most severe), 19581961 (19th), and 2000-2004 (tied for 23rd). In contrast, the $1500 \mathrm{~s}, 1700 \mathrm{~s}, 1800 \mathrm{~s}$, and $1400 \mathrm{~s}$ all contain a higher number of persistent and severe droughts. The longest and highest magnitude uninterrupted droughts are 1703-1718 (16 years) and 1870-1883 (14 years), and the most intense drought in years where EPS exceeds 0.85 was 1504-1507.

The analysis of clusters of droughts separated only by individual years above the instrumental mean (Table 6) more strongly emphasizes the shorter duration droughts in the runs analysis. For example, the

TABLE 1. Descriptive Statistics for Tree-Ring Chronologies Used to Reconstruct Flows for the Weber River.

\begin{tabular}{lllccc}
\hline Site Name & Species & $\begin{array}{c}\text { Time Span } \\
\text { (year A.D.) }\end{array}$ & Year EPS >0.85 & No. Trees & $\begin{array}{c}\text { Interseries } \\
\text { Correlation }\end{array}$ \\
\hline TNR (new) & PIED & $1313-2011$ & 1470 & 29 & 55 \\
RSM (new) & PIED & $1428-2011$ & 1480 & 30 & 52 \\
WED (UT528) & PIED & -218 to 2007 & 440 & 67 & 77 \\
HAR (UT530) & PSME & -322 to 2005 & -217 & 58 & 0.73 \\
\hline
\end{tabular}

Note: TNR, Tanner Ridge; RSM, Rattlesnake Mountain; WED, Well's Draw Update; HAR, Harmon Canyon; PIED, Pinus edulis; PSME, Pseudotsuga menziesii; EPS, expressed population signal. 


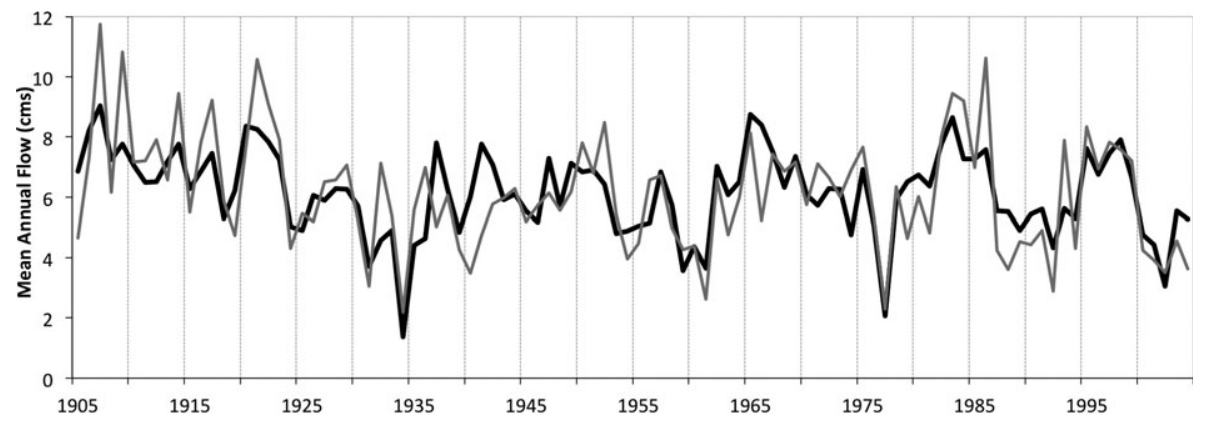

FIGURE 2. Observed (gray line) and Modeled (black line) Water-Year (October-September) Mean Annual Flow (cms) for the Weber River from 1905 to 2004.

TABLE 2. Calibration and Verification Statistics for the Reconstruction. Values in parentheses indicate verification based on first differenced data.

\begin{tabular}{lccccc}
$\begin{array}{l}\text { Calibration } \\
\text { Period }\end{array}$ & $\boldsymbol{R}^{\mathbf{2}}$ & Adj $\boldsymbol{R}^{\mathbf{2}}$ & $\mathbf{R E}$ & $\mathbf{C E}$ & $\begin{array}{l}\text { Durbin- } \\
\text { Watson }\end{array}$ \\
\hline $1905-1954$ & 0.49 & 0.47 & $0.58(0.43)$ & $0.55(0.43)$ & 1.91 \\
$1955-2004$ & 0.63 & 0.62 & $0.48(0.29)$ & $0.44(0.29)$ & 1.86 \\
$1905-2004$ & 0.55 & 0.54 & & & 1.88 \\
\hline
\end{tabular}

Note: RE, reduction of error; CE, coefficient of efficiency.

individual droughts of 1626-1632 and 1634-1639 combine to produce a 14-year period with only one above the mean, and that is of higher magnitude and intensity than the two uninterrupted runs that exceed 10 years. In the $1900 \mathrm{~s}$, the period from 1953 to 1961 also has only one year above the mean but the drought is of lower magnitude and intensity than the uninterrupted 1930-1936 period.

\section{Extreme Wet Periods}

Extreme wet years are also a regular feature of the reconstruction, but are less common in the 1900s than in any other century (Tables 3 and 4). The
1600 s and 1400 s both have very high numbers of individual wet years. Based on runs analysis scores, 4 of the 25 wettest periods occur in the 1900s (Table 5) and although they all have relatively low scores, 1903-1917 is the longest continuous wet period. The $1600 \mathrm{~s}$ include 7 of the 25 wettest runs, including the highest in magnitude despite being only eight years in length (1614-1621). Continuous wet periods are also common in the 1500s. The analysis of clusters of wet periods separated only by individual years below the mean shows that 1903-1923 is the longest wet period that is separated by only one dry year. The period from 1601-1621 is the highest magnitude wet period despite two years below the mean, and $1608-1621$ is the most intense.

\section{DISCUSSION}

The calibration/verification statistics indicate a successful reconstruction, with the caveat that there is no way to test the stability of the relationship between the effects of precipitation and evaporation on streamflow and ring-width increment through the full reconstruction period. The stronger relationship

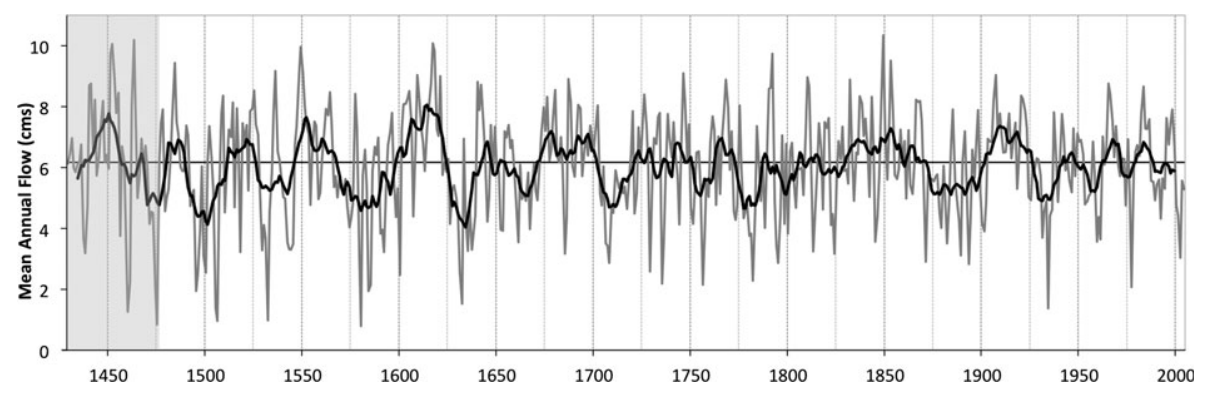

FIGURE 3. Reconstruction of Water-Year (October-September) Mean Annual Flow (cms) for the Weber River from 1429 to 2004 ,

Showing Annual Values (gray line) and an 11-Year Running Average (black line). Gray shading indicates the period from

1429 to 1480 where the expressed population signal drops below 85\% due to reduced sample depth in the Rattlesnake Mountain chronology, and consequently less confidence is placed in the reconstruction. The instrumental mean $(6.15 \mathrm{cms})$ is also shown for comparison. 
TABLE 3. Ranking of the 29 (5th percentile) Driest and Wettest Years in the Reconstruction. Bold indicates years in the instrumental record.

\begin{tabular}{|c|c|c|}
\hline Rank & Dry Years & Wet Years \\
\hline 1 & 1580 & 1849 \\
\hline 2 & 1475 & 1463 \\
\hline 3 & 1506 & 1617 \\
\hline 4 & 1532 & 1452 \\
\hline 5 & 1460 & 1549 \\
\hline 6 & 1934 & 1618 \\
\hline 7 & 1505 & 1451 \\
\hline 8 & 1632 & 1792 \\
\hline 9 & 1495 & 1853 \\
\hline 10 & 1584 & 1484 \\
\hline 11 & 1977 & 1536 \\
\hline 12 & 1474 & 1746 \\
\hline 13 & 1756 & 1550 \\
\hline 14 & 1585 & 1907 \\
\hline 15 & 1735 & 1609 \\
\hline 16 & 1461 & 1621 \\
\hline 17 & 1782 & 1810 \\
\hline 18 & 1600 & 1548 \\
\hline 19 & 1496 & 1453 \\
\hline 20 & 1500 & 1687 \\
\hline 21 & 1631 & 1832 \\
\hline 22 & 1729 & 1768 \\
\hline 23 & 1893 & 1640 \\
\hline 24 & 1708 & 1616 \\
\hline 25 & 1795 & 1965 \\
\hline 26 & 1871 & 1441 \\
\hline 27 & 2002 & 1642 \\
\hline 28 & 1499 & 1440 \\
\hline 29 & 1889 & 1811 \\
\hline
\end{tabular}

TABLE 4. Number of Years by Century Included in the 5th Percentile of the Driest and Wettest Years in the Reconstruction. The first year of the reconstruction is 1429 , so years in the 1400 s are presented as a percentage of 72 years.

\begin{tabular}{lcc}
\hline Century & Dry Years & Wet Years \\
\hline $1900 \mathrm{~s}$ & 2 & 2 \\
$1800 \mathrm{~s}$ & 3 & 5 \\
$1700 \mathrm{~s}$ & 6 & 3 \\
$1600 \mathrm{~s}$ & 3 & 8 \\
$1500 \mathrm{~s}$ & 7 & 4 \\
$1400 \mathrm{~s}$ & 9.6 & 9.6 \\
\hline
\end{tabular}

when calibration was performed on the more recent half of the observed values is likely reflective of decreasing quality in the instrumental record further back in time. The greater skill of the model in predicting dry vs. wet years is typical of tree-ring reconstructions because in extremely wet years tree growth is limited by some other factor such as soil nutrients, and additional moisture no longer benefits growth. The reconstruction confirms observed dry and wet periods, and like streamflow and precipitation reconstructions from surrounding areas, our study also suggests that severe drought years and extended dry periods were common occurrences over the past 576 years and are often well outside the range of the instrumental record (e.g., Gray et al., 2004, 2011; Woodhouse and Lukas, 2006b; Woodhouse et al., 2006, 2010; Meko et al., 2007; Watson et al., 2009; Barnett et al., 2010; Knight et al., 2010; Wise, 2010a). The four chronologies selected from our original, regional pool were all located east of the crest of the Wasatch Mountains, highlighting the importance of rain shadow conditions in increasing tree-ring sensitivity to moisture in this area. The TNR and RSM chronologies developed as part of this study were the strongest predictors and were critical to the reconstruction, emphasizing the importance of our efforts to expand the spatial coverage of tree-ring data along the eastern edge of the Great Basin.

The reconstructed extreme dry individual years compare favorably with the Gray et al. (2011) reconstruction of three headwater tributaries (Yampa, White, and Little Snake) in the Upper Colorado River Basin (UCRB) in southern Wyoming and northern Colorado. The years 1460, 1496, 1500, 1506, 1532, 1584 , and 2002 coincide particularly well, whereas $1495,1505,1580,1632$, and 1934 were more extreme for the Weber Basin than in the UCRB. The Gray et al. (2011) study and our reconstruction of the Weber have one common predictor (WED) so they are not entirely independent. However, the incorporation of newly collected chronologies near the Weber River helped differentiate regional and local dry years (Figure 5), a critical distinction for local water managers. Therefore, while the results suggest some regionalscale agreement for individual dry years that may be important for understanding large-scale synoptic climatology in the broader region, reconstructed nonsynchronous dry years are likely important indicators of more local conditions.

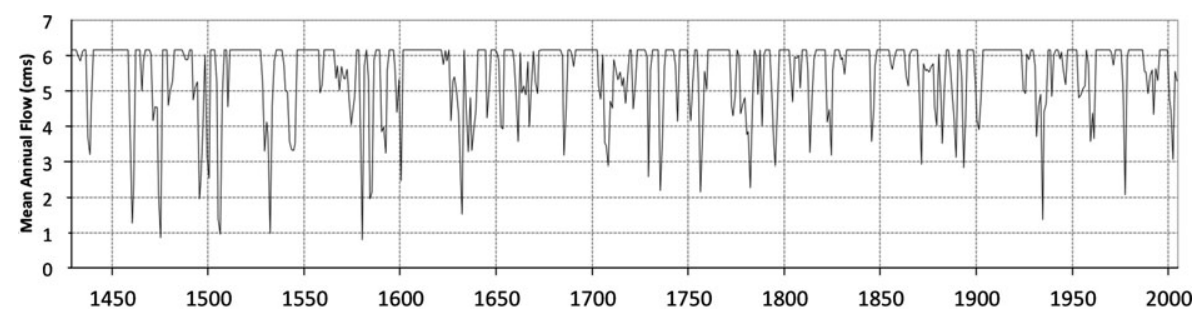

FIGURE 4. Periods of Persistent Drought (two or more years consecutively below the instrumental mean) in the Reconstruction. 
Bekker, DeRose, Buckley, Kuelgren, and Gill

TABLE 5. Periods in the Reconstruction with Consecutive Years below or above the Instrumental Mean, Including Duration, Magnitude (cumulative flow), Intensity (magnitude/duration), and Overall Score (summed magnitude and duration ranks). Dry and wet periods are scored separately and the maximum score is 118 for dry periods and 130 for wet periods. The 25 periods with the highest overall scores are shown, sorted by highest to lowest score. Bold indicates years in the instrumental record. Flow units are cubic meters per second $(\mathrm{cms})$.

\begin{tabular}{|c|c|c|c|c|}
\hline Period & $\begin{array}{c}\text { Duration } \\
\text { (years) }\end{array}$ & $\begin{array}{c}\text { Magnitude } \\
\text { (cms) }\end{array}$ & $\begin{array}{c}\text { Intensity } \\
(\mathrm{cms} / \mathbf{y r})\end{array}$ & Score \\
\hline \multicolumn{5}{|l|}{ Dry } \\
\hline $1492-1500$ & 9 & -20.22 & -2.25 & 110 \\
\hline $1470-1475$ & 6 & -14.61 & -2.44 & 109 \\
\hline $1528-1534$ & 7 & -15.33 & -2.19 & 106 \\
\hline $1504-1507$ & 4 & -12.16 & -3.04 & 106 \\
\hline $1459-1461$ & 3 & -11.26 & -3.75 & 105 \\
\hline $1626-1632$ & 7 & -14.82 & -2.12 & 102 \\
\hline $1583-1586$ & 4 & -9.32 & -2.33 & 99 \\
\hline $1579-1581$ & 3 & -8.77 & -2.92 & 99 \\
\hline $1776-1783$ & 8 & -15.07 & -1.88 & 98 \\
\hline 1930-1936 & 7 & -13.77 & -1.97 & 98 \\
\hline $1634-1639$ & 6 & -12.77 & -2.13 & 98 \\
\hline $1539-1545$ & 7 & -13.69 & -1.96 & 96 \\
\hline 1793-1796 & 4 & -8.89 & -2.22 & 94 \\
\hline $1735-1737$ & 3 & -7.08 & -2.36 & 92 \\
\hline $1590-1593$ & 4 & -7.99 & -2.00 & 88 \\
\hline $1437-1439$ & 3 & -6.87 & -2.29 & 88 \\
\hline $1703-1718$ & 16 & -20.58 & -1.29 & 86 \\
\hline $1755-1759$ & 5 & -9.01 & -1.80 & 84 \\
\hline 1958-1961 & 4 & -7.28 & -1.82 & 81 \\
\hline $1822-1825$ & 4 & -7.27 & -1.82 & 79 \\
\hline $1870-1883$ & 14 & -16.35 & -1.17 & 78 \\
\hline 1892-1894 & 3 & -5.85 & -1.95 & 71 \\
\hline 2000-2004 & 5 & -7.70 & -1.54 & 72 \\
\hline $1597-1600$ & 4 & -6.76 & -1.69 & 72 \\
\hline 1886-1889 & 4 & -6.69 & -1.67 & 70 \\
\hline \multicolumn{5}{|l|}{ Wet } \\
\hline $1451-1455$ & 5 & 14.19 & 2.84 & 127 \\
\hline $1614-1621$ & 8 & 18.00 & 2.25 & 125 \\
\hline $1790-1792$ & 3 & 8.47 & 2.82 & 121 \\
\hline $1546-1553$ & 8 & 15.40 & 1.92 & 120 \\
\hline $1601-1606$ & 6 & 10.61 & 1.77 & 113 \\
\hline $1462-1464$ & 3 & 7.21 & 2.40 & 111 \\
\hline $1640-1644$ & 5 & 8.54 & 1.71 & 109 \\
\hline $1440-1443$ & 4 & 7.49 & 1.87 & 107 \\
\hline $1848-1850$ & 3 & 7.06 & 2.35 & 106 \\
\hline $1523-1527$ & 5 & 8.02 & 1.60 & 105 \\
\hline 1866-1869 & 4 & 7.46 & 1.86 & 105 \\
\hline $1482-1486$ & 5 & 7.58 & 1.52 & 101 \\
\hline $1809-1811$ & 3 & 6.29 & 2.10 & 101 \\
\hline $1852-1854$ & 3 & 5.98 & 1.99 & 99 \\
\hline $1687-1688$ & 2 & 4.73 & 2.37 & 99 \\
\hline $1560-1565$ & 6 & 7.96 & 1.33 & 97 \\
\hline $1608-1612$ & 5 & 7.43 & 1.49 & 96 \\
\hline $1766-1769$ & 4 & 6.95 & 1.74 & 96 \\
\hline 1964-1969 & 6 & 7.90 & 1.32 & 95 \\
\hline 1903-1917 & 15 & 16.17 & 1.08 & 92 \\
\hline 1919-1923 & 5 & 7.14 & 1.43 & 91 \\
\hline $1979-1986$ & 8 & 8.92 & 1.11 & 89 \\
\hline $1508-1509$ & 2 & 3.81 & 1.90 & 86 \\
\hline $1673-1683$ & 11 & 11.37 & 1.03 & 83 \\
\hline $1691-1693$ & 3 & 4.48 & 1.49 & 82 \\
\hline
\end{tabular}

TABLE 6. Clusters in the Reconstruction of Consecutive Years below (above) the Instrumental Mean, Punctuated Only by Single Years above (below) Average, Including Duration, Magnitude (cumulative flow), Intensity (magnitude/duration), Total Number of Years below (above) the Mean, and Overall Score (summed magnitude and duration ranks). Dry and wet clusters were scored separately and the maximum score is 22 for dry clusters and 46 for wet clusters. All clusters in the reconstruction are shown, sorted by highest to lowest score. Bold indicates years in the instrumental record. Flow units are cubic meters per second $(\mathrm{cms})$.

\begin{tabular}{lccccc}
\hline & & & & Years & \\
Period & $\begin{array}{c}\text { Magnitude } \\
\text { (cms) }\end{array}$ & $\begin{array}{c}\text { Intensity } \\
\text { (cms/yr) }\end{array}$ & $\begin{array}{c}\text { Duration } \\
\text { (yrs) }\end{array}$ & $\begin{array}{c}<\text { or }> \\
\text { Mean }\end{array}$ & Score \\
\hline Dry & & & & & \\
$1626-1639$ & -26.80 & -1.91 & 14 & 1 & 20 \\
$1622-1639$ & -27.41 & -1.52 & 18 & 2 & 20 \\
$1579-1586$ & -17.66 & -2.21 & 8 & 1 & 16 \\
$1772-1783$ & -17.98 & -1.50 & 12 & 1 & 15 \\
$1772-1789$ & -20.34 & -1.13 & 18 & 3 & 11 \\
$1772-1786$ & -18.24 & -1.22 & 15 & 2 & 11 \\
$1776-1789$ & -17.43 & -1.24 & 14 & 2 & 10 \\
$1622-1632$ & -15.43 & -1.40 & 11 & 1 & 10 \\
$1776-1786$ & -15.33 & -1.39 & 11 & 1 & 10 \\
$\mathbf{1 9 5 3 - 1 9 6 1}$ & -11.31 & -1.26 & 9 & 1 & 7 \\
$1785-1789$ & -3.55 & -0.71 & 5 & 1 & 2 \\
Wet & & & & & \\
$1608-1621$ & 25.15 & 1.80 & 14 & 1 & 45 \\
$1601-1621$ & 34.01 & 1.62 & 21 & 2 & 44 \\
$1440-1455$ & 24.73 & 1.55 & 16 & 2 & 40 \\
$1445-1455$ & 17.67 & 1.61 & 11 & 1 & 38 \\
$1848-1854$ & 12.49 & 1.78 & 7 & 1 & 36 \\
$1440-1458$ & 22.88 & 1.20 & 19 & 3 & 35 \\
$1546-1557$ & 16.87 & 1.41 & 12 & 1 & 34 \\
$1601-1612$ & 16.30 & 1.25 & 13 & 1 & 32 \\
$1451-1458$ & 12.33 & 1.54 & 8 & 1 & 31 \\
$\mathbf{1 9 0 3 - 1 9 2 3}$ & 22.45 & 1.07 & 21 & 1 & 30 \\
$1445-1458$ & 15.82 & 1.13 & 14 & 2 & 28 \\
$1440-1449$ & 10.74 & 1.07 & 10 & 1 & 22 \\
$1519-1527$ & 10.30 & 1.14 & 9 & 1 & 22 \\
$1691-1702$ & 11.13 & 0.93 & 12 & 1 & 21 \\
$1512-1527$ & 11.84 & 0.74 & 16 & 3 & 16 \\
$1832-1844$ & 10.57 & 0.81 & 13 & 2 & 16 \\
$1832-1841$ & 8.99 & 0.90 & 10 & 1 & 15 \\
$1516-1527$ & 9.39 & 0.78 & 12 & 2 & 13 \\
$1835-1844$ & 8.95 & 0.90 & 10 & 1 & 13 \\
$1512-1517$ & 4.47 & 0.63 & 6 & 1 & 8 \\
$1512-1521$ & 4.74 & 0.47 & 10 & 2 & 6 \\
$1816-1821$ & 4.13 & 0.69 & 6 & 1 & 5 \\
$1516-1521$ & 2.29 & 0.38 & 6 & 1 & 2 \\
\hline & & & & &
\end{tabular}

Longer term dry events indicated by the runs and clusters analyses also show similar patterns with previous streamflow reconstructions throughout the Intermountain West. For example, the longest continuous period on the Yampa identified by Gray et al. (2011) was 1704-1717, which coincides almost exactly with the longest on the Weber (1703-1718) (see Figure 5). In addition, one of the most severe clusters (1579-1586) on the Weber matches very well with an 11-year continuous drought on the Yampa. 


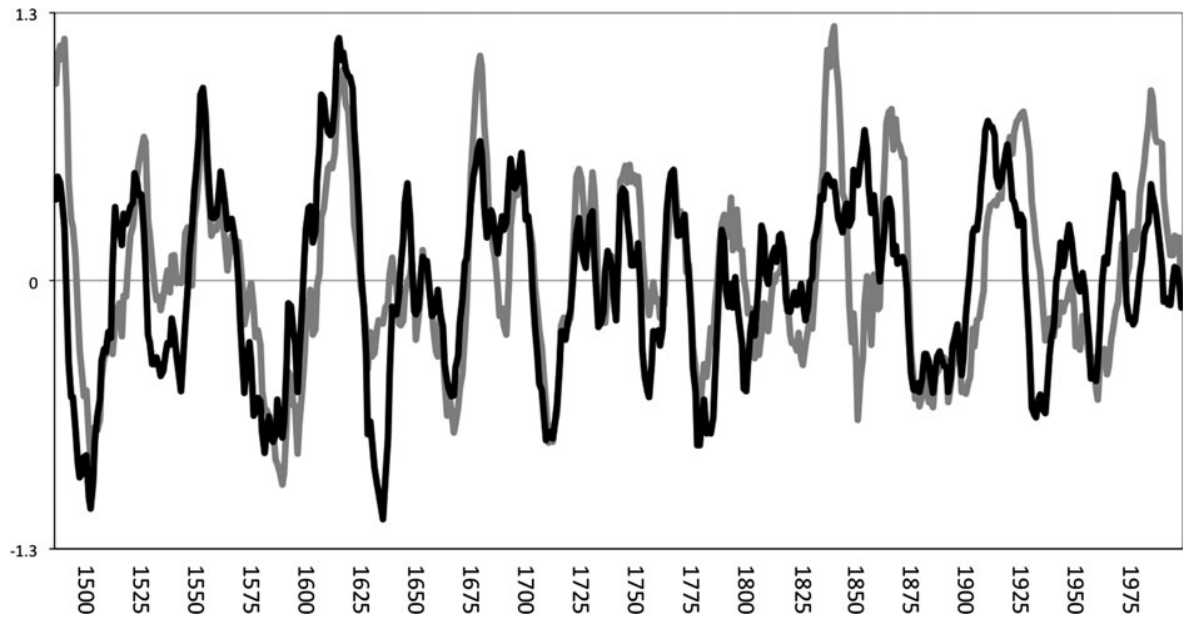

FIGURE 5. Eleven-Year Running Means of Reconstructed Water-Year Flow for the Weber (black line) and Yampa (Gray et al., 2011) (gray line) Rivers, Highlighting Both Coherent Regional and Discontinuous, Localized Dry and Wet Periods. The reconstruction is shown only for the period where expressed population signal exceeds 0.85 for the Weber (after 1480).

On the main stem of the Colorado at Lees Ferry, Woodhouse et al. (2006) reconstructed low-flow events similar to 1579-1586, 1626-1639, 1703-1718, 1772-1789, and 1879-1883 on the Weber. West of the Weber Basin, in the Spring Valley watershed of eastern Nevada (Strachan et al., 2012), low-flow events were generally similar to those on the Weber in 1504-1507, 1583-1586, 1626-1632, 1930-1936, and 1958-1961, but the dry periods in Spring Valley were typically shorter than in the Weber Basin. Finally, in the Snake River Basin in Wyoming (Wise, 2010a), an extensive dry period coincided with the 1626-1639 event on the Weber, as well as 1930-1936 and 2000-2004, but in general dry periods in the 1900s were more severe for the Snake than for the Weber.

Extreme wet years and periods have not been scrutinized as closely as dry events in many streamflow reconstructions in the Intermountain West. Nevertheless, the early 1900s pluvial is evident in the UCRB (e.g., Woodhouse et al., 2006; Gray et al., 2011), Spring Valley (Strachan et al., 2012), and the Snake (Wise, 2010a). In contrast, the early 1600s pluvial is much stronger (magnitude, duration, and intensity) than the early 1900 s or 1980 s for the Weber River, while it is only slightly stronger or similar for most of the UCRB and Spring Valley reconstructions, and weaker for the Snake. The extreme early 1600s pluvial is a striking feature of nearly all Wasatch Front tree-ring chronologies (Allen et al., 2013) and should be the subject of future study.

\section{Application to Water Management}

Improvements of risk assessment are possible by incorporating previously unknown extreme events that are indicated by the reconstruction. By pairing historical extreme events with comparable events during the instrumental record, water managers can broaden their expectations on system behavior. Extreme individual dry years on the Weber River have occurred during the instrumental period that are comparable with those from the previous four centuries, particularly 1934, 1977, and 2002. However, there is no modern analog for the continuous multiyear dry events seen in the reconstruction. The most severe continuous drought during the instrumental period occurred between 1930 and 1936, and was exceeded in magnitude by 7 events, in duration by 4 , and in intensity by 13 over the period of the reconstruction. Moreover, the period from 1622-1639 had only two years above mean annual flow and exceeded the most extreme continuous events in the instrumental period in duration and magnitude. The only multidrought cluster in the instrumental period was 1953-1961, which was lower in magnitude than 1930-1936.

Following a wet 2011 water year, northern Utah experienced dry conditions in 2012 and 2013. As of the end of July 2013, reservoirs in the Weber Basin were at $52 \%$ of capacity, and the Weber Basin Water Conservancy District had implemented a 20\% acrossthe-board cut to wholesale irrigation recipients (O’Donoghue, 2013). Mean annual flow for water year 2012 was 3.7 cubic meters per second ( $\mathrm{cms})$, a little above the observed 2002 value of $3.5 \mathrm{cms}$ (USGS, 2013). Assuming water year 2013 produces the same value of $3.7 \mathrm{cms}$, the magnitude (cumulative departure from the instrumental mean) for this two-year drought would be $-4.9 \mathrm{cms}$ and the intensity would be -2.5 . This intensity exceeds several in the reconstruction, but droughts matching that intensity in 
Bekker, DeRose, Buckley, Kuelgren, and Gill

the Weber reconstruction have lasted as long as four years. If current conditions continued for one or two more years, reservoir capacity could easily drop to zero, and additional cuts in water delivery would certainly be necessary. A less intense but longer duration drought such as the 1703-1718 event might prove even more problematic. If the intensity of this drought $(-1.29)$ over four years were to produce the same deficit as -2.5 over two, then after those four years, reservoir capacity would be close to $50 \%$ with 12 continuous dry years to follow.

Given the lack of modern analogs for these multiyear drought events, another option for risk assessment and mitigation is to incorporate tree-ring data into existing quantitative water system models to more adequately assess worst-case scenarios. For example, one western water agency found that their current water management plan could accommodate a worstcase drought based on a 45-year instrumental record without imposing water restrictions, but could only withstand the worst drought in the tree-ring record with severe restrictions in place. Consequently, they began considering changes to operations that would prevent the need for restrictions (Rice et al., 2009).

Because floods are more strongly associated with extreme weather events than climate, the reconstructed wet periods do not necessarily indicate severe flooding. Nevertheless, some of the worst floods in the state have been associated with pluvials, such as in the early $1980 \mathrm{~s}$, and spring runoff management can be difficult under consistently wet conditions. The Weber reconstruction agrees with observations that the early 1900s pluvial was wetter than the 1980s, but the early 1600 s were much wetter still. Multiple, consecutive, wet years such as 1983-1986 can strain storage and result in increased levels of the closedbasin outlet for the Weber River, the Great Salt Lake. Given that the 1980s pluvial resulted in substantial flooding and damage along the Wasatch Front (Morrisette, 1988), the longer duration, more intense early $1600 \mathrm{~s}$ pluvial should supersede the 1980 s as the most extreme event for matters of water management planning.

\section{CONCLUSION}

We have provided the first tree-ring reconstruction for a major river that is being increasingly utilized for municipal and agricultural purposes along the metropolitan and rapidly growing Wasatch Front. Uncertainty is a hallmark of this region's hydroclimate, and climatic change will only increase that uncertainty. We have attempted to reduce that uncer- tainty by improving the spatial and temporal coverage of tree-ring data surrounding the major rivers serving the Wasatch Front, and producing a 576-year perspective on variability for the Weber River. The reconstruction suggests that the instrumental record paints an overly optimistic picture of extreme drought and flood conditions, as dry and wet periods of greater magnitude, duration, and intensity have occurred previously. Although the past cannot predict future conditions, reconstructed extreme years and periods can be used in water management as a basis for the assessment of drought and flood risk, including as inputs to forecast models or in water depletion scenarios for reservoir management.

\section{ACKNOWLEDGMENTS}

We thank Chelsea Decker, Kimball Hansen, Joseph Naylor V, and Matthew Collier for assistance in the field and laboratory. We also thank Jeff Lukas and Connie Woodhouse for helpful advice and the contributors to the International Tree-Ring Data Bank. Three anonymous reviewers provided helpful comments that improved the manuscript. Funding was provided by Brigham Young University, the Charles Redd Center for Western Studies, and US Bureau of Reclamation WaterSmart Grant No. R13AC80039. This study was prepared in part by an employee of the US Forest Service as part of official duties and is therefore in the public domain. This is a contribution of the Wasatch Dendroclimatology Research Group (WADR) and LDEO contribution number 7769 .

\section{LITERATURE CITED}

Allen, E.B., T.M. Rittenour, R.J. DeRose, M.F. Bekker, R. Kjelgren, and B.M. Buckley, 2013. A Tree-Ring Based Reconstruction of Logan River Streamflow, Northern Utah Range. Water Resources Research 49:8579-8588, doi: 10.1002/2013WR014273.

Barnett, F.A., S.T. Gray, and G.A. Tootle, 2010. Upper Green River Basin (United States) Streamflow Reconstructions. Journal of Hydrologic Engineering 15:567-579, doi: 10.1061/(ASCE)HE.19435584.0000213.

Briffa, K.R., 1995. Interpreting High-Resolution Proxy Climate Data - The Example of Dendroclimatology. In: Analysis of Climate Variability: Applications of Statistical Techniques, Proceedings of an Autumn School Organized by the Commission of the European Community on Elba from October 30 to November 6, 1993, H. von Storch and A. Navarra (Editors). Springer Verlag, Berlin, pp. 77-94.

Brown, D.P. and A.C. Comrie, 2004. A Winter Precipitation "Dipole" in the Western United States Associated with Multidecadal ENSO Variability. Geophysical Research Letters 31: L02903, doi: 10.1029/2003GL018726.

Carson, E.C. and J.S. Munroe, 2005. Tree-Ring Based Streamflow Reconstructions for Ashley Creek, Northeastern Utah: Implications for Paleohydrology of the Southern Uinta Mountains. The Holocene 15(4):602-611.

Cayan, D.R., K.T. Redmond, and L.G. Riddle, 1999. ENSO and Hydrologic Extremes in the Western United States. Journal of Climate 12:2881-2893.

Cook, E.R., P.J. Krusic, R.H. Holmes, and K. Peters, 2007. Program ARSTAN Version 41d. http://www.ldeo.columbia.edu/tree-ringlaboratory/resources/software, accessed May 2013. 
DeRose, R.J., S.-Y. Wang, and J.D. Shaw, 2013. Feasibility of High-Density Climate Reconstruction Based on Forest Inventory and Analysis (FIA) Collected Tree-Ring Data. Journal of Hydrometeorology 14:375-381.

DNR (Department of Natural Resources), 2007. Drought in Utah: Learning from the Past, Preparing for the Future. Utah State Water Plan. Utah Division of Water Resources. http://www. water.utah.gov/droughtreport/binder2A.pdf, accessed August 2013.

Draper, N.R. and H. Smith, 1998. Applied Regression Analysis (Third Edition). Wiley, New York City, New York.

Friedman, J.H., 1984. A Variable Span Smoother. Technical Report 5. Laboratory for Computational Statistics, Department of Statistics, Stanford University, Stanford, California.

Fritts, H.C., 1976. Tree Rings and Climate. Academic Press, New York City, New York.

Fritts, H.C., 1991. Principal Components. In: Reconstructing Large-Scale Climatic Patterns from Tree-Ring Data, H.C. Fritts (Editor). University of Arizona Press, Tucson, Arizona, pp. 4457.

Fritts, H.C., J. Guiot, G.A. Gordon, and F. Schweingruber, 1990. Methods of Calibration, Verification, and Reconstruction. In: Methods of Dendrochronology: Applications in the Environmental Sciences, E.R. Cook and L.A. Kariukstis (Editors). Kluwer Academic Publishers, Dordrecht, The Netherlands, pp. 163-218.

Gray, S.T., S.T. Jackson, and J.L. Betancourt, 2004. Tree-Ring Based Reconstructions of Interannual to Decadal-Scale Precipitation Variability for Northeastern Utah Since 1226 A.D. Journal of the American Water Resources Association 40:947-960.

Gray, S.T., J.J. Lukas, and C.A. Woodhouse, 2011. MillennialLength Records of Streamflow from Three Major Upper Colorado River Tributaries. Journal of the American Water Resources Association 47(4):702-712, doi: 10.1111/j/1752-1688. 2011.00535.x.

Hidalgo, H.G., J.A. Dracup, G.M. MacDonald, and J.A. King, 2001. Comparison of Tree Species Sensitivity to High- and LowExtreme Hydroclimatic Events. Physical Geography 22(2):115134.

Holmes, R.L., 1983. Cofecha Version 6.06. http://www.ldeo.columbia.edu/tree-ring-laboratory/resources/software, accessed May 2013.

Knight, T.A., D.M. Meko, and C.H. Baisan, 2010. A BimellenialLength Tree-Ring Reconstruction of Precipitation for the Tavaputs Plateau, Northeastern Utah. Quaternary Research 73:107-117.

Mackun, P. and S. Wilson, 2011. Population Distribution and Change: 2000 to 2010. U.S. Census Briefs, U.S. Census Bureau. http://www.census.gov/prod/cen2010/briefs/c2010br-01.pdf, accessed August 2013.

Meko, D.M. and C.W. Stockton, 1984. Secular Variations in Streamflow in the Western United States. Journal of Climate and Applied Meteorology 23:889-897.

Meko, D.M., C.A. Woodhouse, C.H. Baisan, T. Knight, J.J. Lukas, M.K. Hughes, and M.W. Salzer, 2007. Medieval Drought in the Upper Colorado River Basin. Geophysical Research Letters 34: L10705, doi: 10.1029/2007GLO29988.

Meko, D.M., C.A. Woodhouse, and K. Morino, 2012. Dendrochronology and Links to Streamflow. Journal of Hydrology 412-413:200209.

Mock, C.J., 1996. Climatic Controls and Spatial Variations of Precipitation in the Western United States. Journal of Climate 9:1111-1125.

Morrisette, P.M., 1988. The Rising Level of the Great Salt Lake: Impacts and Adjustments. Bulletin of the American Meteorological Society 69(9):1034-1040.

O’Donoghue, A.I., 2013. Record-Breaking Heat and Drought Sear Utah and the West. Deseret News, Sunday, June 30. http://
www.deseretnews.com/article/865582439/Record-breaking-heatdrought-sear-Utah-the-West.html?pg=all, accessed August 2013.

Pederson, G.T., S.T. Gray, C.A. Woodhouse, J.L. Betancourt, D.B. Fagre, J.S. Littell, E. Watson, B.H. Luckman, and L.J. Graumlich, 2011. The Unusual Nature of Recent Snowpack Declines in the North American Cordillera. Sciencexpress 333(6040):332335, doi: 10.1126/science.1201570.

Pope, D. and C. Brough (Editors), 1996. Utah's Weather and Climate. Publishers Press, Salt Lake City, Utah.

Rice, J.L., C.A. Woodhouse, and J.J. Lukas, 2009. Science and Decision-Making: Water Management and Tree-Ring Data in the Western United States. Journal of the American Water Resources Association 45(5):1248-1259, doi: 10.1111/j.1752-1688. 2009.00358.x.

Seager, R., M. Ting, I. Held, Y. Kushnir, J. Lu, G. Vecchi, H.-P. Huang, N. Harnik, A. Leetmaa, N.-C. Lau, C. Li, J. Velez, and N. Naik, 2007. Model Projections of an Imminent Transition to a More Arid Climate in Southwestern North America. Science 316:1181-1184.

Speer, J.H., 2010. Fundamentals of Tree-Ring Research. University of Arizona Press, Tucson, Arizona, 333 pp.

Strachan, S., F. Biondi, and J. Leising, 2012. 550-Year Reconstruction of Streamflow Variability in Spring Valley, Nevada. Journal of Water Resources Planning and Management 138:326-333.

Tingstad, A.H. and G.M. MacDonald, 2010. Long-Term Relationships between Ocean Variability and Water Resources in Northeastern Utah. Journal of the American Water Resources Association 46:987-1002.

UDWR (Utah Division of Water Resources), 2009. Weber River Basin - Planning for the Future. Utah State Water Plan. http:// www.water.utah.gov, accessed May 2013.

USGS (U.S. Geological Survey), 2013. National Water Information System. Gauge 10128500, Weber River near Oakley, UT. http:// waterdata.usgs.gov/usa/nwis, accessed May 2013.

Wang, S.-Y., R.R. Gillies, J. Jin, and L.E. Hipps, 2010. Coherence between the Great Salt Lake Level and the Pacific Quasi-Decadal Oscillation. Journal of Climate 23:2161-2177.

Watson, T.A., F.A. Barnett, S.T. Gray, and G.A. Tootle, 2009. Reconstructed Streamflows for the Headwaters of the Wind River, Wyoming, United States. Journal of the American Water Resources Association 45(1):224-236, doi: 10.111/j. 1752-1688.2008.00274.x.

Wigley, T.M.L., K.R. Briffa, and P.D. Jones, 1984. On the Average Value of Correlated Time Series, with Applications in Dendroclimatology and Hydrometeorology. Journal of Climate and Applied Meteorology 23:201-213.

Wise, E.K., 2010a. Tree Ring Record of Streamflow and Drought in the Upper Snake River. Water Resources Research 46:W11529, doi: 10.1029/2010WR009282.

Wise, E.K., 2010b. Spatiotemporal Variability of the Precipitation Dipole Transition Zone in the Western United States. Geophysical Research Letters 37:L07706, doi: 10.1029.

Wise, E.K., 2012. Hydroclimatology of the US Intermountain West. Progress in Physical Geography 36:458-479.

Woodhouse, C.A., 2001. A Tree-Ring Reconstruction of Streamflow for the Colorado Front Range. Journal of the American Water Resources Association 37(3):561-569.

Woodhouse, C.A., S.T. Gray, and D.M. Meko, 2006. Updated Streamflow Reconstructions for the Upper Colorado River Basin. Water Resources Research 42:W05415, doi: 10.1029/2005WR004455.

Woodhouse, C.A. and P.A. Kay, 1990. The Use of Tree-Ring Chronologies to Show Spatial and Temporal Changes in an Air Mass Boundary. Physical Geography 11:172-190.

Woodhouse, C.A. and J.J. Lukas, 2006a. Drought, Tree Rings and Water Resource Management in Colorado. Canadian Water Resources Journal 31(4):1-14. 
Bekker, DeRose, Buckley, Kuelgren, and Gill

Woodhouse, C.A. and J.J. Lukas, 2006b. Multi-Century Tree-Ring Reconstructions of Colorado Streamflow for Water Resource Planning. Climatic Change 78:293-315.

Woodhouse, C.A., D.M. Meko, G.M. MacDonald, D.W. Stahle, and E.R. Cook, 2010. A 1,200-Year Perspective of 21st Century Drought in Southwestern North America. Proceedings of the National Academy of Sciences of the United States of America 107:21283-21288.

Woodhouse, C.A., J.L. Russell, and E.R. Cook, 2009. Two Modes of North American Drought from Instrumental and Paleoclimatic Data. Journal of Climate 22:4336-4347, doi: 10.1175/2009 JCLI2705.1. 